Original Article

\title{
Performance evaluation of the commercial aquafeeds available in the market of Pakistan on Channa marulius (Sole)
}

\author{
Avaliação de desempenho dos alimentos aquáticos comerciais disponíveis no mercado \\ do Paquistão em Channa marulius (Sole)

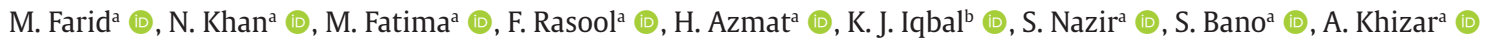 \\ and M. Asghar ${ }^{\mathrm{a}}$ (D) \\ aUniversity of Veterinary and Animal Sciences, Department of Fisheries and Aquaculture, Lahore, Pakistan \\ 'Islamia University of Bahawalpur, Department of Zoology, Bahawalpur, Pakistan
}

\begin{abstract}
The present study aimed to determine the effect of different levels of protein on the growth, body composition, amino acid profile and serology of Channa marulius fingerlings. The experiment was conducted in ten happas installed in earthen ponds, each stocked with 10 fishes for 90 days. Four commercial fish feeds having 25\%,30\%,32\% and $40 \%$ crude protein (CP) levels were fed to fish at $3 \%$ of their wet body weight three times a day. The results of the study revealed that highest weight gain, feed conversion ratio and survival rate were observed in $30 \%$ protein feed. Meanwhile, moisture content was higher in fish fed with $30 \% \mathrm{CP}$ feed while highest crude protein was recorded in $40 \% \mathrm{CP}$ fed fish. Lowest fat content was observed in 32\% CP feed. Amino acid profile of fish revealed better results in 30\% CP feed. Total protein, glucose and globulin were also highest in fish feeding $30 \%$ CP feed, while albumin was highest in $40 \%$ CP feed. It is concluded that 30\% CP feed showed better results in terms of growth, amino acid profile and serological parameters without effecting fish body composition.
\end{abstract}

Keywords: crude protein, amino acids, Channa marulius, body composition, serology.

\begin{abstract}
Resumo
O presente estudo teve como objetivo determinar o efeito de diferentes níveis de proteína sobre o crescimento, composição corporal, perfil de aminoácidos e sorologia de alevinos de Channa marulius. 0 experimento foi conduzido em dez happas instalados em tanques de terra, cada um abastecido com 10 peixes, por 90 dias. Quatro alimentos para peixes comerciais com níveis de $25 \%, 30 \%, 32 \%$ e $40 \%$ de proteína bruta (PB) foram dados aos peixes com 3\% de seu peso corporal úmido três vezes ao dia. Os resultados do estudo revelaram que maior ganho de peso, taxa de conversão alimentar e taxa de sobrevivência foram observados em 30\% de proteína alimentar. Enquanto isso, o conteúdo de umidade foi maior em peixes alimentados com $30 \%$ de PB, enquanto a proteína bruta mais alta foi registrada em peixes alimentados com 40\% de PB. O menor conteúdo de gordura foi observado em rações com $32 \%$ de PB. O perfil de aminoácidos dos peixes revelou melhores resultados na ração com $30 \%$ de PB. Proteína total, glicose e globulina também foram maiores em peixes alimentados com ração com $30 \%$ de PB, enquanto a albumina foi mais alta com 40\% de PB. Conclui-se que a ração com 30\% de PB apresentou melhores resultados em termos de crescimento, perfil de aminoácidos e parâmetros sorológicos sem afetar a composição corporal dos peixes.
\end{abstract}

Palavras-chave: proteína bruta, aminoácidos, Channa marulius, composição do corpo, sorologia.

\section{Introduction}

Aquaculture production has been increased since last three decades to meet the protein demand across the globe (Cruz-Cervantes et al., 2018). Aquaculture industry plays a significant role to meet the demand of meat and also recognized as fastest food processing industry (Baruah et al., 2004; Iqbal et al., 2014). Protein is one of the most essential components to enhance growth performance of fish. To maintain body energy and to synthesize body protein, dietary protein provides essential and non- essential amino acids (Hossain et al., 2010).
The requirement of protein in animals varies with age, species, size and reproductive state and environment (NRC, 2011). The percentage of quality protein in feed results in effective growth particularly in carnivorous fish species (Lee et al., 2002). For proper growth of fish best level of protein is an important factor for feed formulation. To maintain their several life process fish require energy which it obtain from feed in the form of protein (Okorie et al., 2007) Protein deficient feed results in poor growth, by converting nitrogenous wastes into energy through oxidation of amino acids (Wu and Gatlin III, 2014). 
The rapid development and low entry barriers for feed industry has revolutionized the Pakistan fish production due to targeted feed for aquaculture. The feed engineering especially enriched with protein has been tried in a variety of fish species (Sealey et al., 2013). Add references here. Hua et al. (2019) has confirmed the reliant of aquafeed industry is on wild captured forage fish protein. Similarly, insect protein based meal were fed to the atlantic salmon to evaluate the impact on growth performance. Quality analysis of fish feed is mostly carried out on the growth rate of fish and quality benefit of fish. Amino acid is an important energy source and is essential for fish growth to achieve nutritional significance (Santos et al., 2011). The amino acids are found abundantly in fish which are essential for maintaining health (Yin et al., 2010). Secondly, serum biochemistry (protein \& carbohydrate) is an important measure to determine the health status of fish (Fazio et al., 2015). Biochemical attributes like protein, albumin, glucose and globulin served as indicator of biological status of fish (Gupta, 2014).

Channa marulius (Hamilton, 1822) locally known as 'Sol' is the largest among the murrel species. Channa marulius is a hardy fish and it has reasonable growth and is popular for its flesh quality (Marimithu et al., 2001). The feeding nature is carnivore but can consume and digest feed which is based on various plant origin with high level of protein (Hafeez-ur-Rehman et al., 2017).

Keeping in view the importance of artificial feed, the current study was designed to determine the effect of different levels of protein feeds on growth of $C$. marulius. As there is no specific feed of sole available in the market, this experiment was aimed to test the commercially available different $\mathrm{CP}$ feeds for $C$. marulius and their effect was evaluated on growth, body composition and amino acid profile of fish.

\section{Materials and Methods}

The trial was conducted in happas installed in earthen ponds having dimension of $20 \times 15 \times 10$ '. Average weight of the fish was $141.23 \pm 1.18 \mathrm{~g}$. The design of study was completely randomized (CRD). The four commercially available diets of different CP level viz; T1 (40\% CP), T2 (32\% CP), T3 (30\% CP), T4 (25\% CP) were fed to fish in three replicates, and each treatment was stocked with 10 fish. Channa marulius was used as experimental fish and grouped into four treatments. The feed was fed to fish at $3 \%$ of their body weight three times a day for two months.

\subsection{Growth parameters}

Different parameters of growth, for example, net weight gain, percentage weight gain, feed conversion ratio (FCR) and specific growth rate (SGR\%) was calculated by the following the formulae of Hopkins (1992) (Equations 1, 2 and 3$)$.

Net weight gain $(N W G)=$ Average final weight $(g)$ - Averageinitial weight $(g)$

Percent weight gain $=\left(\begin{array}{l}\text { Final weight }(g)-\text { Initial weight }((g)) / \\ \text { Initial weight }(g)\end{array}\right) \times 100$

Feed Conversion Ratio $(F C R)=$ Feed intake $(g) /$ Wet weight gain $(g)$

\subsection{Proximate analysis}

Five fish from each replicate was taken and dried in oven for 24 hours at $70{ }^{\circ} \mathrm{C}$ for whole body proximate. The dry samples were grinded in pestle and mortar to make powder of fish samples and kept in zip packets and stored in refrigerator for further studying its chemical composition. After that samples were analyzed for moisture, crude protein, crude fat and ash, by following the methods of AOAC (2006). The samples were dried at $105{ }^{\circ} \mathrm{C}$ for the determination of moisture content. The crude protein was determined by estimation of nitrogen after acid digestion $\left(\mathrm{N}_{2} \times 6.025\right)$ by using the Kjeldhal's apparatus at Fish nutrition department of UVAS. The Soxhlet apparatus was used to determine the crude fat by ether extraction method. Crude ash was determined by flaming the sample at $660{ }^{\circ} \mathrm{C}$ (Fatima et al., 2019).

\subsection{Amino acids profile}

Amino acids profile of experimental fish muscle was analyzed by using amino acid analyzer (Biochrome $30^{+}$ Model) available at Dr. M. Yaqoob Malik amino acid analysis laboratory at UVAS, Ravi Campus Pattoki, using ion exchange chromatography described by Official Journal of European Communities using amino acids analyser (Biochrom 30+ Model) known as gold standard for AAA (Michel et al., 2020).

\subsection{Serum biochemistry and physicochemical parameters}

Three fish from each treatment was randomly chosen for the collection of blood. Serum was obtained by centrifugation of sample at 1200rpm for 10 minutes. Biochemical parameters in the serum samples were analyzed for total protein, albumin, glucose, and globulin using an automated chemistry analyzer following protocol described by Salze et al. (2016). Water temperature, $\mathrm{pH}$, dissolved oxygen, total dissolved solid and electrical conductivity of water was recorded on daily basis. The turbidity was measured by the secchi disc.

\section{Statistical Analysis}

The resulting data was analyzed by one way analysis of variance (ANOVA) through SAS version 9.1. Means were compared by using Duncan's Multiple Range Test with a significance level $\mathrm{P} \leq 0.05$ (Steel et al., 1996).

\section{Results}

\subsection{Growth parameters}

At the end of trial, the results of growth performance were analyzed by one way ANOVA and presented in Table 1 . The growth parameters were observed maximum in diet containing $30 \% \mathrm{CP}$, while minimum growth was observed in the diet containing $25 \% \mathrm{CP}$.

\subsection{Body composition}

The body composition of fish showed non-significant $(\mathrm{p} \geq 0.05)$ results among all the treatments and shown in 
Table 1. Growth parameters of Channa marulius among different treatments.

\begin{tabular}{lcccc}
\hline \multicolumn{1}{c}{ Treatments } & T1 40\% CP & T2 32\% CP & T3 30\% CP & T4 25\% CP \\
\hline Initial Weight $(\mathbf{g})$ & $140.37 \pm 2.30$ & $141.30 \pm 1.42$ & $142.87 \pm 2.57$ & $140.36 \pm 1.48$ \\
Final Weight $(\mathbf{g})$ & $165.5 \pm 2.57^{\mathrm{c}}$ & $167.50 \pm 0.70^{\mathrm{c}}$ & $184.97 \pm 0.54^{\mathrm{a}}$ & $174.5 \pm 1.62^{\mathrm{b}}$ \\
Net Weight Gain (g) & $25.13 \pm 0.43^{\mathrm{c}}$ & $26.20 \pm 1.79^{\mathrm{c}}$ & $42.10 \pm 2.29^{\mathrm{a}}$ & $32.14 \pm 0.51^{\mathrm{b}}$ \\
Percent weight gain & $17.85 \pm 0.27^{\mathrm{c}}$ & $18.43 \pm 1.45^{\mathrm{c}}$ & $29.57 \pm 2.09^{\mathrm{a}}$ & $24.28 \pm 0.41^{\mathrm{b}}$ \\
FCR $^{\mathrm{a}}$ & $5.83 \pm 0.10^{\mathrm{a}}$ & $4.64 \pm 0.30^{\mathrm{b}}$ & $3.05 \pm 0.25^{\mathrm{c}}$ & $3.70 \pm 0.07^{\mathrm{c}}$ \\
SGR \% $^{\mathrm{b}}$ & $0.23 \pm 0.03^{\mathrm{d}}$ & $0.29 \pm 0.02^{\mathrm{c}}$ & $0.43 \pm 0.03^{\mathrm{a}}$ & $0.36 \pm 0.01^{\mathrm{b}}$ \\
Survival \% & $90 \pm 5.7^{\mathrm{b}}$ & $80 \pm 10^{\mathrm{c}}$ & $100 \pm 5.77^{\mathrm{a}}$ & $100 \pm 15.27^{\mathrm{a}}$ \\
\hline
\end{tabular}

The date represents the mean of three replicates. ${ }^{\mathrm{a}} \mathrm{FCR}=$ Feed conversion ratio; ${ }^{\mathrm{b} S G R}(\%)=$ Specific growth rate.

Table 2. Proximate analysis of Channa marulius among different treatments.

\begin{tabular}{lrrrr}
\hline \multicolumn{1}{c}{ Treatments } & T1 40\% CP & T2 32\% CP & T3 30\% CP & T4 25\% CP \\
\hline Moisture (\%) & $61.25 \pm 1.67^{\mathrm{c}}$ & $62.38 \pm 0.78^{\mathrm{c}}$ & $69.93 \pm 2.28^{\mathrm{a}}$ & $63.17 \pm 1.07^{\mathrm{b}}$ \\
Crude Protein (\%) & $31.29 \pm 0.98^{\mathrm{a}}$ & $29.28 \pm 1.63^{\mathrm{a}}$ & $21.02 \pm 1.85^{\mathrm{c}}$ & $23.12 \pm 0.90^{\mathrm{b}}$ \\
Crude Fat (\%) & $2.42 \pm 0.26^{\mathrm{b}}$ & $2.29 \pm 0.36^{\mathrm{b}}$ & $2.49 \pm 0.21^{\mathrm{b}}$ & $4.32 \pm 0.09^{\mathrm{a}}$ \\
Ash (\%) & $4.71 \pm 0.92^{\mathrm{a}}$ & $4.58 \pm 1.44^{\mathrm{b}}$ & $4.03 \pm 0.84^{\mathrm{b}}$ & $4.78 \pm 0.07^{\mathrm{a}}$ \\
NFE (\%) & $0.33 \pm 0.35^{\mathrm{b}}$ & $0.57 \pm 0.26^{\mathrm{a}}$ & $0.53 \pm 0.12^{\mathrm{a}}$ & $0.61 \pm 0.04^{\mathrm{a}}$ \\
\hline
\end{tabular}

The date represents the mean of three replicates. ${ }^{\mathrm{N}} \mathrm{NFE}(\%)=$ Nitrogen free extract.

Table 3. The Amino acid profile of $C$. marulius among different treatments.

\begin{tabular}{clcccc}
\hline & \multicolumn{1}{c}{ TREATMENT } & T1 40\%CP & T2 32\%CP & T3 30\%CP & T4 25\%CP \\
\hline Essential & Methionine & $1.33 \pm 0.07^{\mathrm{b}}$ & $1.30 \pm 0.04^{\mathrm{b}}$ & $3.08 \pm 0.08^{\mathrm{a}}$ & $0.55 \pm 0.08^{\mathrm{c}}$ \\
amino acid & Threonine & $2.28 \pm 0.05^{\mathrm{b}}$ & $2.32 \pm 0.19^{\mathrm{a}}$ & $1.77 \pm 0.12^{\mathrm{c}}$ & $2.39 \pm 0.09^{\mathrm{a}}$ \\
$\begin{array}{c}\text { \%of dry } \\
\text { matter) }\end{array}$ & Valine & $2.15 \pm 0.05^{\mathrm{b}}$ & $2.29 \pm 0.21^{\mathrm{a}}$ & $1.71 \pm 0.09^{\mathrm{c}}$ & $2.31 \pm 0.16^{\mathrm{a}}$ \\
& Isoleucine & $3.69 \pm 0.09^{\mathrm{a}}$ & $3.76 \pm 0.28^{\mathrm{a}}$ & $2.91 \pm 0.07^{\mathrm{b}}$ & $3.99 \pm 0.23^{\mathrm{a}}$ \\
& Phenylalanine & $2.01 \pm 0.07^{\mathrm{b}}$ & $2.06 \pm 0.08^{\mathrm{b}}$ & $1.58 \pm 0.30^{\mathrm{c}}$ & $2.19 \pm 0.12^{\mathrm{a}}$ \\
& Histidine & $1.05 \pm 0.01^{\mathrm{a}}$ & $1.1 \pm 0.03^{\mathrm{a}}$ & $0.81 \pm 0.04^{\mathrm{b}}$ & $1.11 \pm 0.06^{\mathrm{a}}$ \\
& Lysine & $4.93 \pm 0.07^{\mathrm{b}}$ & $5.32 \pm 0.05^{\mathrm{a}}$ & $4.09 \pm 0.09^{\mathrm{c}}$ & $5.29 \pm 0.18^{\mathrm{a}}$ \\
Non- & Aysteine & $0.58 \pm 0.05^{\mathrm{a}}$ & $0.62 \pm 0.06^{\mathrm{c}}$ & $0.35 \pm 0.06^{\mathrm{c}}$ & $0.55 \pm 0.01^{\mathrm{b}}$ \\
Essential & Aspartic acid + & $3.52 \pm 0.02^{\mathrm{b}}$ & $3.35 \pm 0.01^{\mathrm{c}}$ & $3.08 \pm 0.04^{\mathrm{d}}$ & $3.65 \pm 0.19^{\mathrm{a}}$ \\
$\begin{array}{c}\text { (\%of dry } \\
\text { matter) }\end{array}$ & Serine & & & & \\
& Glutamic acid +Glutamine & $2.25 \pm 0.04^{\mathrm{b}}$ & $2.3 \pm 0.08^{\mathrm{a}}$ & $1.76 \pm 0.12^{\mathrm{c}}$ & $2.34 \pm 0.09^{\mathrm{a}}$ \\
& Glycine & $6.98 \pm 0.01^{\mathrm{b}}$ & $6.85 \pm 0.06^{\mathrm{b}}$ & $6.04 \pm 0.29^{\mathrm{c}}$ & $8.05 \pm 0.81^{\mathrm{a}}$ \\
& Alanine & $4.12 \pm 0.02^{\mathrm{a}}$ & $4.16 \pm 0.08^{\mathrm{a}}$ & $3.52 \pm 0.19^{\mathrm{b}}$ & $4.3 \pm 0.04^{\mathrm{a}}$ \\
& Tyrosine & $3.33 \pm 0.11^{\mathrm{b}}$ & $3.36 \pm 0.23^{\mathrm{b}}$ & $2.77 \pm 0.16^{\mathrm{c}}$ & $3.54 \pm 0.17^{\mathrm{a}}$ \\
& Arginine & $1.19 \pm 0.20^{\mathrm{b}}$ & $1.28 \pm 0.05^{\mathrm{b}}$ & $0.97 \pm 0.07^{\mathrm{b}}$ & $1.39 \pm 0.13^{\mathrm{a}}$ \\
& Proline & $0.92 \pm 0.07^{\mathrm{b}}$ & $0.81 \pm 0.03^{\mathrm{c}}$ & $0.83 \pm 0.04^{\mathrm{c}}$ & $1.07 \pm 0.21^{\mathrm{a}}$ \\
& Ornithine & $2.65 \pm 0.08^{\mathrm{b}}$ & $2.8 \pm 0.41^{\mathrm{a}}$ & $2.18 \pm 0.28^{\mathrm{b}}$ & $2.78 \pm 0.06^{\mathrm{a}}$ \\
\hline
\end{tabular}

The data represents the mean of three replicates.

Table 2 . The maximum moisture \% was observed in the diet having 30\% CP while the crude protein and ash \% was minimum in this diet. The crude fat and nitrogen free extract was maximum in the diet containing $25 \% \mathrm{CP}$.

\subsection{Amino acid profile}

At the end of experimental trial, the fish were analyzed for amino acid profile. The fluctuating results were observed among all the essential and non-essential amino acids in the diets containing different $\mathrm{CP}$ levels and shown in Table 3.25\% CP showed increase level of valine, threonine, isoleucine, phenylalanine, histidine, lysine, aspartic acid, serine, glutamic acid, glycine, alanine, tyrosine, arginine, proline and ornithine. While 32\% CP showed increase level of threonine, valine, isoleucine, histidine, lysine, serine, glysine, proline, and ornithine.

\subsection{Serum parameters and physicochemical parameters}

The serum parameters were analyzed from each treatment and shown in Table 4. The total protein, globulin and glucose content was highest in the $30 \% \mathrm{CP}$ diet while the albumin content was highest in 40\% CP diet. The significantly different results were observed among all treatments. Meanwhile, all the physicochemical parameters were showed non-significant results in all treatments and shown in Table 5. 
Table 4. Comparison of serum parameters among different treatment.

\begin{tabular}{lrrrr}
\hline \multicolumn{1}{c}{ Treatments } & T1 40\%CP & T2 32\% CP & T3 30\% CP & T4 25\% CP \\
\hline Total protein $\left(\mathbf{g l}^{-1}\right)$ & $3.37 \pm 0.12^{\mathrm{c}}$ & $3.51 \pm 0.02^{\mathrm{b}}$ & $3.89 \pm 0.11^{\mathrm{a}}$ & $3.12 \pm 0.05^{\mathrm{d}}$ \\
Albumin $\left(\mathbf{g l}^{-1}\right)$ & $1.19 \pm 0.01^{\mathrm{a}}$ & $1.03 \pm 0.01^{\mathrm{b}}$ & $1.03 \pm 0.04^{\mathrm{b}}$ & $1.08 \pm 0.01^{\mathrm{b}}$ \\
Glucose $(\mathbf{m m o l} / \mathbf{L})$ & $55 \pm 2.82^{\mathrm{c}}$ & $60 \pm 3.53^{\mathrm{b}}$ & $75 \pm 2.12^{\mathrm{a}}$ & $72 \pm 1.41^{\mathrm{a}}$ \\
Globulin $\left(\mathbf{g l}^{-1}\right)$ & $2.18 \pm 0.11^{\mathrm{c}}$ & $2.48 \pm 0.01^{\mathrm{b}}$ & $2.86 \pm 0.07^{\mathrm{a}}$ & $2.04 \pm 0.04^{\mathrm{c}}$ \\
\hline
\end{tabular}

The data represents the mean of three replicates.

Table 5. Comparison of water quality parameters among different treatments.

\begin{tabular}{lcccc}
\hline \multicolumn{1}{c}{ Treatments } & T1 40\% CP & T2 32\% CP & T3 30\% CP & T4 25\% CP \\
\hline Temperature $\left({ }^{\circ} \mathbf{C}\right)$ & $20.55 \pm 2.54$ & $21.00 \pm 2.53$ & $21.14 \pm 2.53$ & $21.14 \pm 2.45$ \\
pH & $7.97 \pm 0.38$ & $7.97 \pm 0.44$ & $7.83 \pm 0.44$ & $7.80 \pm 0.44$ \\
TDS $(\mathbf{m g} / \mathbf{l})^{\mathrm{a}}$ & $1412.08 \pm 160.91$ & $1413.51 \pm 196.62$ & $1434.01 \pm 224.12$ & $1425.78 \pm 223.16$ \\
DO $\left(\mathbf{m g} / \mathbf{l}^{\mathrm{b}}\right.$ & $3.97 \pm 0.24$ & $3.99 \pm 0.26$ & $4.01 \pm 0.26$ & $4.02 \pm 0.26$ \\
$\mathbf{E C}(\mu \mathbf{S} / \mathbf{c m})^{\mathrm{c}}$ & $3757.41 \pm 87.56$ & $3783.00 \pm 66.43$ & $3796.88 \pm 69.68$ & $3792.35 \pm 72.73$ \\
Turbidity $(\mathbf{c m})$ & $10.66 \pm 1.10$ & $10.68 \pm 1.20$ & $10.81 \pm 1.21$ & $10.82 \pm 1.31$ \\
\hline
\end{tabular}

The date represents the mean of three replicates. ${ }^{\mathrm{T}} \mathrm{TDS}=$ Total dissolved solid; ${ }^{\mathrm{b}} \mathrm{DO}=$ Dissolved oxygen; ${ }^{\mathrm{c}} \mathrm{EC}=$ Electrical conductivity.

\section{Discussion}

In our study the highest growth rate of fish was recorded in $30 \%$ protein diet, after which a decrease in growth was observed. Usually, fish growth increase when level of the protein in diet increases (NRC,1993). Though, growth of the fish increase at a certain level, beyond that level growth of the fish not increase by increasing protein in diet or may become the cause of decrease in growth (Gunasekera et al., 2000; Kim and Lall, 2001; Hossain et al., 2010). In this experiment, specific growth rate and weight gain enhanced in the $30 \%$ supplemented protein diet as the then, growth performance was decreased. The maximum growth at $30 \%$ in our study was observed may be due to the bigger initial weight of fish, as in most of the requirement studies fish fingerling of smaller sizes and weights are used. The protein requirements of some other fish species were also investigated, such as protein requirement of black sea bass was $45.3 \%$ (Shah Alam et al., 2008), European sea bass was 45\% (Perez et al.,1997) and olive flounder was $46.4 \%$ (Kim et al., 2002). The results from this study, though, are less than the protein requirements of grouper, (47.8\%; Chen and Tsai, 1994) and silver pomfret (49\%; Hossain et al., 2010) and higher than those of hybrid striped bass (40\%; Gatlin III et al., 1994) and white bass (41\%; Rudacille and Kohler 1998), however, fish used in these studies were of smaller sizes.

The protein content in fish body was best recorded with $30 \%$ protein diet. Muscle protein is most reported protein deposition source among different parts of the fish (Ghassem et al., 2014). The quality of fish flesh was determined by the protein content (Caulton and Bursell., 1977). The lipid contents were decreased with the increase in protein level as were observed in tilapia by Jauncy and Ross (1982). In our study, inverse relationship was found between fat and protein contents. However, moisture and ash content has not shown any linear pattern when fed with different treatment levels. Similar results were also reported by Maithya (1998), in African catfish.

The amino acids are important biochemical constituent for the healing of wound and recovery as described by Westaby (1985). Amino acid profile of fish produced similar results with Jais et al. (1998). Glutamic acid showed the highest amount in the profile in C. marulius. This relates to the statement of Ghomi et al. (2012) who observed the highest value of glutamic acid in amino acid composition of flesh of cold water rainbow trout. The most abundant amino acid observed in C. marulius was glutamic acid, aspartic acid, lysine and isoleucine.

The serum biochemical parameters can reflect fish health status and nutritional metabolism as described by Lin et al. (2015). Based on the analysis, the fish which was fed with $30 \%$ diet has highest concentrations of total protein and glucose. Similar results were reported in African catfish by Abdel-Tawwab et al. (2007). In our study, the highest concentration of albumin was observed in fish which was fed with $40 \%$ protein diet.

The water quality parameters directly affect the fish metabolism and food intake efficiency as described by Mutlu et al. (2016). According to Boyd (1979) examined no adverse effects of water quality parameter on the growth and survival rate of fish. In our study, the level of turbidity increase as the quantity of feed increases which directly affect the feeding rate. Although, the strong negative correlation was existing between turbidity and feeding level which suggests that increased turbidity may reduce the feeding rate as reported by Rowe and Dean (1998).

The results of the study indicated that $30 \%$ protein diet showed best results of WG, FCR and SGR. The dry matter, crude protein, crude fat and ash content were also improved in 30\% diet. Serum biochemistry i.e., total protein, glucose and globulin showed better results at 30\% 
protein level. In conclusion, the results of the experiment suggested that the diet containing $30 \%$ protein can support maximum growth under the experimental conditions used in this study.

\section{Acknowledgements}

The authors are thankful to Punjab Agricultural Research Board (PARB) funded research project (no. 695) under which this study was conducted at Department of Fisheries \& Aquaculture, UVAS, Ravi Campus, Pattoki.

\section{References}

ABDEL-TAWWAB, M., MOUSA, M.A. and ABBASS, F.E., 2007. Growth performance and physiological response of African catfish, Clarias gariepinus (B.) fed organic selenium prior to the exposure to environmental copper toxicity. Aquaculture, vol. 272, no. 1-4, pp. 335-345. http://dx.doi.org/10.1016/j. aquaculture.2007.09.004

SHAH ALAM, M., WATANABE, W.O. and CARROLL, P.M., 2008. Dietary protein requirements of juvenile black sea bass, Centropristis striata. Journal of the World Aquaculture Society, vol. 39, no. 5, pp. 656-663.

ASSOCIATION OF OFFICIAL AGRICULTURAL CHEMISTS - AOAC, 2006. Official methods of analysis. Philadelphia: AOAC Press.

BARUAH, K., SAHU, N.P., PAL, A.K. and DEBNATH, D. 2004 [viewed 8 April 2021]. Dietary phytase: an ideal approach for a cost effective and low-polluting aquafeed. WorldFish Center Quarterly [online], vol. 27, no. 3-4, pp. 15-19. Available from: https://hdl. handle.net/20.500.12348/2061

BOYD, C.E., 1979. Water quality in warmwater fishponds. Auburn: Auburn Univerity, 359 p.

CAULTON, M.S. and BURSELL, E., 1977. The relationship between changes in condition and body composition in young Tilapia rendolli Boulenger. Journal of Fish Biology, vol. 11, no. 2, pp. 143-150. http://dx.doi.org/10.1111/j.1095-8649.1977.tb04107.x.

CHEN, H.Y. and TSAI, J.C., 1994. Optimal dietary protein level for the growth of juvenile grouper, Epinephelus malabaricus, fed semipurified diets. Aquaculture (Amsterdam, Netherlands), vol. 119, pp. 265-271.

CRUZ-CERVANTES, J.A., BENAVIDES-GONZ, A.F., JESUS GENARO, S., ANCHEZ-MART, N., AZQUEZ-SAUCEDAA, M.L.V. and RUIZ-URIBE, A.J., 2018. Propolis in aquaculture: a review of its potential. Reviews in Fisheries Science \& Aquaculture, vol. 26, no. 3, pp. 337-349. http://dx.doi.org/10.1080/23308249.2018.1424798.

FATIMA, M., AFZAL, M. and SHAH, S.Z.H., 2019. Effect of dietary oxidized oil and vitamin $\mathrm{E}$ on growth performance, lipid peroxidation and fatty acid profile of Labeo rohita fingerlings. Aquaculture Nutrition, vol. 25, no. 2, pp. 281-291. http://dx.doi. org/10.1111/anu.12851.

FAZIO, F., SAOCA, C., CASELLA, S., FORTINO, G. and PICCIONE, G., 2015. Relationship between blood parameters and biometric indices of Sparus aurata and Dicentrarcus labrax cultured in onshore tanks. Marine and Freshwater Behaviour and Physiology, vol. 48, no. 4, pp. 289-296. http://dx.doi.org/10.1080/102362 44.2015.1041239.

GATLIN III, D.M., BROWN, M.L., KEEMBIYEHETTY, C.N., JARAMILLO JUNIOR, F. and NEMATIPOUR, G.R., 1994. Nutritional requirements of hybrid striped bass (Morone chrysops $\times M$. saxatilis). Journal of the World Aquaculture Society, vol. 33, pp. 97-109.

GHASSEM, M., FERN, S.S., SAID, M., ALI, Z.M., IBRAHIM, S. and BABJI, A.S., 2014. Kinetic characterization of Channa striatus muscle sarcoplasmic and myofibrillar protein hydrolysates. Journal of Food Science and Technology, vol. 51, no. 3, pp. 467-475. http:// dx.doi.org/10.1007/s13197-011-0526-6. PMid:24587521.

GHOMI, M.R., DEZHABAD, A., DALIRIE, M.S., NIKOO, M., TOUDAR, S., SOHRABNEJAD, M. and BABAEI, Z., 2012. Nutritional properties of kutum, Rutilus frisii kutum (Kamensky), silver carp, Hypophthalmichthys molitrix (Val.), and rainbow trout, Oncorhynchus mykiss (Walbaum), correlated with body weight. Fisheries \& Aquatic Life, vol. 20, no. 4, pp. 275-280. https://doi. org/10.2478/v10086-012-0031-1.

GUNASEKERA, R.M., SILVA, S.S., COLLINS, R.A., GOOLEY, G. and INGRAM, B.A., 2000. Effect of dietary protein level on growth and food utilization in juvenile Murray cod, Maccollochella peelii peelii (Michell). Aquaculture Research, vol. 31, no. 2, pp. 181-187. http://dx.doi.org/10.1046/j.1365-2109.2000.00417.x.

GUPTA, R.C., 2014. Biomarkers in toxicology. 1st ed. Boston: Academic Press.

HAFEEZ-UR-REHMAN, M., ABBAS, F., ASHRAF, M., NAREJO, N.T., IQBAL, K.J., ABBAS, G. and ANDLEEB, S., 2017. Effect of different dietary protein levels on egg development and its response to inducing agents during induced spawning of Channa marulius. Pakistan Journal of Zoology, vol. 49, no. 1, pp. 337-343. http:// dx.doi.org/10.17582/journal.pjz/2017.49.1.337.343.

HOPKINS, K.D., 1992. Reporting fish growth: a review of the basics 1. Journal of the World Aquaculture Society, vol. 23, no. 3, pp. 173-179. http://dx.doi.org/10.1111/j.1749-7345.1992.tb00766.x.

HOSSAIN, M.A., ALMATAR, S.M. and JAMES, C.M., 2010. Optimum dietary protein level for juvenile silver pomfret, Pampus argenteus (Euphrasen). Journal of the World Aquaculture Society, vol. 41, no. 5, pp. 710-720. http://dx.doi.org/10.1111/j.17497345.2010.00413.x.

HUA, K., COBCROFT, J.M., COLE, A., CONDON, K., JERRY, D.R., MANGOTT, A., PRAEGER, C., VUCKO, M.J., ZENG, C., ZENGER, K. and STRUGNELL, J.M., 2019. The future of aquatic protein: implications for protein sources in aquaculture diets. One Earth, vol. 1, no. 3, pp. 316-329. http://dx.doi.org/10.1016/j. oneear.2019.10.018.

IQBAL, R., ALI, M., NAREJO, N.T. and UMER, K., 2014. Effect of varying levels of protein from different animal sources on growth and survival of carp, Cirrhinus mrigala, reared in cemented cisterns. Pakistan Journal of Zoology, vol. 46, no. 6, pp. 1599-1604. https:// doi.org/0030-9923/2014/0006-1599.

JAIS, A.M.M., MATORI, M.F., KITTAKOOP, P. and SOWANBORIRUX, K., 1998. Fatty acid composition in mucus and roe of Haruan, Channa striatus, for wound healing. General Pharmacology: The Vascular System, vol. 30, no. 4, pp. 561-563. http://dx.doi. org/10.1016/S0306-3623(97)00305-4. PMid:9522175.

JAUNCY, K. and ROSS, B., 1982. A guide to tilapia feeds and feeding. Scotland: Institute of Aquaculture, University of Stirling.

KIM, J.D. and LALL, S.P., 2001. Effects of dietary protein level on growth and utilization of protein and energy by juvenile haddock (Melanogrammus aeglefinus). Aquaculture, vol. 195, no. 3-4, pp. 311-319. http://dx.doi.org/10.1016/S0044-8486(00)00562-7.

KIM, K.W., WANG, X.J. and BAI, S.C., 2002. Optimum dietary protein level for maximum growth of juvenile olive flounder, Paralichthys olivaceus (Temminck et Schlegel). Aquaculture Research, vol. 33, no. 9, pp. 673-679. http://dx.doi.org/10.1046/j.13652109.2002.00704.x. 
LEE, S.M., JEON, I.G. and LEE, J.Y., 2002. Effects of digestible protein and lipid levels in practical diets on growth, protein utilization and body composition of juvenile rockfish (Sebastes schlegeli). Aquaculture, vol. 211, no. 1-4, pp. 227-239. http://dx.doi. org/10.1016/S0044-8486(01)00880-8.

LIN, H., TAN, X., ZHOU, C., NIU, J., XIA, D., HUANG, Z., WANG, J. and WANG, Y., 2015. Effect of 702 dietary arginine levels on the growth performance, feed utilization, non-specific immune response and disease resistance of juvenile golden pompano Trachinotus ovatus. Aquaculture, vol. 437, pp. 382-389. http:// dx.doi.org/10.1016/j.aquaculture.2014.12.025.

MAITHYA, J., 1998 [viewed 8 April 2021]. The evolution of body muscle composition of the African catfish (Clarias gariepinus) (Burchell, 1822). Naga: the ICLARM Quarterly [online], vol. 21, no. 2, pp. 24-26. Available from: http://www.worldfishcenter. org/Naga/na_2298.pdf

MARIMITHU, K., HANIFFA, M.A., AROCKIARAK, A.J. and MURUGANANDAM, M., 2001. Spawning and parental behavior in the induced breed murrels. Indian Journal of Fisheries, vol. 48, no. 4, pp. 409-411.

MICHEL, M., SALVADOR, C., WIEDEMAIR, V., ADAM, M.G., LASER, K.T., DUBOWY, K.O., ENTENMANN, A., KARALL, D., GEIGER, R., ZLAMY, M. and SCHOLL-BÜRGI, S., 2020. Method comparison of HPLC-ninhydrin-photometry and UHPLC-PITC-tandem mass spectrometry for serum amino acid analyses in patients with complex congenital heart disease and controls. Metabolomics, vol. 16, no. 12, pp. 1-10. http://dx.doi.org/10.1007/s11306-02001741-8. PMid:33319318.

MUTLU, E., KUTLU, B. and DEMIR, T., 2016. Assessment of Çinarli Stream (Hafik-Sivas)'S water quality via physico-chemical methods. Turkish Journal of Agriculture-Food Science and Technology, vol. 4, no. 4, pp. 267-278. http://dx.doi.org/10.24925/ turjaf.v4i4.267-278.494.

NATIONAL RESEARCH COUNCIL - NRC, 1993. Nutrient requirements of fish. Washington: National Academy Press.

NATIONAL RESEARCH COUNCIL - NRC, 2011. Nutrient requirements of fish and shrimp. Washington: National Academy Press, $392 \mathrm{p}$.

OKORIE, E.O., KIM, Y.C., LEE, S., BAE, J.Y., YOO, J.H., HAN, K., BAI, S.C., PARK, G.J. and CHOI, S.M., 2007. Reevaluation of the dietary protein requirements and optimum dietary protein to energy ratios in Japanese eel, Anguilla japonica. Journal of the World Aquaculture Society, vol. 38, no. 3, pp. 418-426. http://dx.doi. org/10.1111/j.1749-7345.2007.00113.x.
PEREZ, L., GONZALEZ, H., JOVER, M. and FERNÁNDEZ-CARMONA, J.F., 1997. Growth of European sea bass fingerlings (Dicentrarchus labrax) fed diets containing varying levels of protein, lipid and carbohydrate. Aquaculture, vol. 156, no. 3-4, pp. 187-197. http:// dx.doi.org/10.1016/S0044-8486(97)00089-6.

ROWE, D.K. and DEAN, L.T., 1998. Effect of turbidity on the feeding ability of the juvenile migrant stage of six New Zealand freshwater fish species. New Zealand Journal of Marine and Freshwater Research, vol. 32, no. 1, pp. 21-29. http://dx.doi.or g/10.1080/00288330.1998.9516803.

RUDACILLE, J.B. and KOHLER, C.C., 1998. Dietary protein requirement of juvenile white bass, Morone chrysops (book of abstract). Aquaculture, vol. 98, pp. 457-458.

SALZE, G.P., SPANGLER, E., COBINE, P.A., RHODES, M. and DAVIS, D.A., 2016. Investigation of biomarkers of early taurine deficiency in Florida pompano Trachinotus carolinus. Aquaculture, vol. 451, pp. 254-265. http://dx.doi.org/10.1016/j.aquaculture.2015.09.019.

SANTOS, S.A., MARTINS, V.G., SALAS-MELLADO, M. and PRENTICE, C., 2011. Evaluation of functional properties in protein hydrolysates from Bluewing Searobin (Prionotus punctatus) obtained with different microbial enzymes. Food and Bioprocess Technology, vol. 4, no. 8, pp. 1399-1406. http://dx.doi.org/10.1007/s11947009-0301-0.

SEALEY, W.M., GAYLORD, T.G., TONER, M., ILGEN, J., FRASER, W.C., HOOLEY, C.G. and BARROWS, F.T., 2013. Growth and acute temperature tolerance of June Sucker juveniles fed varying dietary protein and lipid levels with and without supplemental dicalcium phosphate. North American Journal of Aquaculture, vol. 75, no. 1, pp. 124-132. http://dx.doi.org/10.1080/152220 55.2012.736449.

STEEL, R.G.D., TORRIE, J.H. and DINKEY, D.A., 1996. Principles and procedures of statistics. 2nd ed. Singapore: McGraw Hill Book Co. .

WESTABY, S., 1985. Wound healing. 2nd ed. New York: Macmillan Press, pp. 2-7.

WU, X. and GATLIN III, D.M., 2014. Effects of altering dietary protein content in morning and evening feedings on growth and ammonia excretion of red drum (Sciaenops ocellatus). Aquaculture, vol. 434, pp. 33-37. http://dx.doi.org/10.1016/j. aquaculture.2014.07.019.

YIN, Y., HUANG, R., LI, T., RUAN, Z., XIE, M., DENG, Z., HOU, Y. and WU, G., 2010. Amino acid metabolism in the portal-drained viscera of young pigs: effects of dietary supplementation with chitosan and pea hull. Amino Acids, vol. 39, no. 5, pp. 1581-1587. http://dx.doi.org/10.1007/s00726-010-0577-4. PMid:20361217. 